\title{
Moderate topsoil erosion rates constrain the magnitude of the erosion-induced carbon sink and agricultural productivity losses on the Chinese Loess Plateau
}

\author{
Jianlin Zhao ${ }^{1,2}$, Kristof Van Oost ${ }^{3}$, Longqian Chen $^{2}$, and Gerard Govers ${ }^{1}$ \\ ${ }^{1}$ Division of Geography, Department of Earth and Environmental Sciences, KU Leuven, Leuven, Belgium \\ ${ }^{2}$ School of Environmental Sciences and Spatial informatics, China University of Mining and Technology, \\ 221006 Xuzhou, China \\ ${ }^{3}$ Earth and Life Institute, Universite Catholique de Louvain, Louvain-la-Neuve, Belgium
}

Correspondence to: Jianlin Zhao (jianlin.zhao@ees.kuleuven.be)

Received: 18 July 2015 - Published in Biogeosciences Discuss.: 10 September 2015

Revised: 7 July 2016 - Accepted: 3 August 2016 - Published: 23 August 2016

\begin{abstract}
Despite a multitude of studies, overall erosion rates as well as the contribution of different erosion processes on Chinese Loess Plateau (CLP) remain uncertain, which hampers a correct assessment of the impact of soil erosion on carbon and nutrient cycling as well as on crop productivity. In this paper we used a novel approach, based on field evidence, to reassess erosion rates on the CLP before and after conservation measures were implemented (1950 vs. 2005). We found that current average topsoil erosion rates are 3 to 9 times lower than earlier estimates suggested. Under 2005 conditions, more sediment was produced by nontopsoil erosion (gully erosion $\left(0.23 \pm 0.28 \mathrm{Gt} \mathrm{yr}^{-1}\right)$ and landsliding $\left(0.28 \pm 0.23 \mathrm{Gt} \mathrm{yr}^{-1}\right)$ combined) than by topsoil erosion (ca. $0.30 \pm 0.08 \mathrm{Gt} \mathrm{yr}^{-1}$ ). Overall, these erosion processes mobilized ca. $4.77 \pm 1.96 \mathrm{Tg} \mathrm{yr}^{-1}$ of soil organic carbon (SOC): the latter number sets the maximum magnitude of the erosion-induced carbon sink, which is ca. 4 times lower than one other recent estimate suggests.
\end{abstract}

The programs implemented from the 1950 s onwards reduced topsoil erosion from $0.51 \pm 0.13$ to $0.30 \pm 0.08 \mathrm{Gt} \mathrm{yr}^{-1}$ while SOC mobilization was reduced from $7.63 \pm 3.52$ to $4.77 \pm 1.96 \mathrm{Tg} \mathrm{C} \mathrm{yr}^{-1}$. Conservation efforts and reservoir construction have disrupted the equilibrium that previously existed between sediment and SOC mobilization on the one hand and sediment and SOC export to the Bohai sea on the other hand: nowadays, most eroded sediments and carbon are stored on land.

Despite the fact that average topsoil losses on the CLP are still relatively high, a major increase in agricultural produc- tivity has occurred since 1980. Fertilizer application rates nowadays more than compensate for the nutrient losses by (topsoil) erosion: this was likely not the case before the dramatic rise of fertilizer use that started around 1980. Hence, erosion is currently not a direct threat to agricultural productivity on the CLP but the long-term effects of erosion on soil quality remain important.

\section{Introduction}

The Chinese Loess Plateau (CLP) is one of the cradles of human civilization: agriculture started in ca. $7500 \mathrm{BC}$ and the first kingdoms appeared around $1000 \mathrm{BC}$ ( $\mathrm{Li}$ et al., 2007). The fertile loess soils of the area are seen as a key factor in explaining this early development (Ho, 1969). Yet, loess soils are also highly sensitive to erosion (Zhang et al., 2004). The intense erosion of soils on the CLP was already described more than 50 years ago and was seen as a major contributor to the relative decline of the area: hence its description as "China's sorrow" (Liu, 1999; Lowdermilk, 1953). Soil erosion on the CLP may not only threaten agricultural soil productivity, but also cause water pollution and reservoir sedimentation (Blanco-Canqui and Lal, 2008; Pimentel et al., 1995) and exacerbate downstream flooding problems in the valley of the Yellow River (Cai, 2001; Tsunekawa et al., 2014). 
The Chinese authorities responded to this situation by initiating major soil conservation efforts on the CLP in two stages: between 1950 and 1990 conservation focused on reducing erosion through infrastructural measures: intensive programs of terracing and check-dam construction were implemented aiming at reducing erosion while maintaining or improving agricultural production (Chen et al., 2007; Shi and Shao, 2000; Zhao et al., 2013). After 1990, efforts focused on reforestation (The Grain for Green program) to curb erosion problems, thereby sacrificing agricultural production in exchange for better land protection and carbon sequestration (Chen et al., 2007; Fu et al., 2011; Sun et al., 2013).

Soil erosion also has a significant impact on elemental cycles. In particular, agricultural erosion has been reported to induce a (small) carbon sink from the atmosphere to the soil, driven by dynamic replacement at eroded sites and soil organic carbon (SOC) burial at depositional sites (Y. Li et al., 2015; Van Oost et al., 2007). Determining the exact magnitude of this sink critically depends on the amount of dynamic SOC replacement, the fate of the eroded carbon as well as the state of the system (Berhe et al., 2007; Harden et al., 1999; Wang et al., 2015). However, the maximum magnitude of the erosion-induced carbon sink is, in general, set by the amount of SOC mobilized by erosion processes (Y. Li et al., 2015).

One recent estimate places the total amount of SOC that is currently annually mobilized by soil erosion on the CLP area at ca. $18 \mathrm{Tg}$ (Ran et al., 2014), which is 1.5 to 2 times the amount of carbon sequestered in biomass (Feng et al., 2013; Persson et al., 2013) and 1 order of magnitude larger than the amount of carbon sequestered in the soils of the CLP as a result of the Grain for Green soil conservation program (Chang et al., 2011; Deng et al., 2013; Shi and Han, 2014; Zhang et al., 2010). This illustrates that soil erosion may significantly affect regional carbon balances (Yue et al., 2016).

Soil erosion not only affects the cycling of $\mathrm{C}$, but also that of major nutrients such as Nitrogen $(\mathrm{N})$ and Phosphorus $(\mathrm{P})$. Global estimates suggest that the total amounts of $\mathrm{N}$ and $\mathrm{P}$ mobilized by erosion are, respectively, ca. $20-40 \%$ and ca. $80-150 \%$ of the total amount of $\mathrm{N}$ and $\mathrm{P}$ applied as mineral fertilizer (Quinton et al., 2010). At the regional scale, nutrient losses by soil erosion can exceed nutrient inputs, thereby reducing soil fertility and generating significant economic and environmental costs (Quinton et al., 2010; Trimble and Crosson, 2000).

The impact of erosion on elemental cycling and soil fertility is not only controlled by the amount of sediments that are being mobilized but also by their source. Soil organic carbon as well as soil nutrients are generally concentrated in the topsoil (Jobbágy and Jackson, 2000, 2001; Liu et al., 2011, 2013): therefore topsoil erosion by rill and interrill erosion will lead to disproportionate losses of both SOC and nutrients from the soil reservoir. Excessive river sediment loads and the siltation of reservoirs, on the other hand, may be caused by a range of erosion processes, including gully erosion and landsliding. These processes will be less important for elemental cycling as they mobilize sediments that contain in general much less SOC and nutrients than topsoil (Han et al., 2010).

Given the fact that topsoil is relatively enriched in nutrients and $\mathrm{C}$ in comparison to subsoil material, quantifying the effect of erosion processes on elemental cycles requires that the contribution of different processes to total sediment production is known. If no distinction between different erosion processes is made, the impact of erosion processes on elemental cycles may be either overestimated or underestimated, depending on the assumptions being made regarding the SOC, $\mathrm{N}$ and $\mathrm{P}$ content of the soil and/or sediment that is mobilized. For instance, if it is assumed that only topsoil is mobilized, the impact of erosion is likely to be overestimated as topsoil contains far more SOC and nutrients than subsoil.

Assessment of topsoil erosion rates over large areas is not straightforward. While measurements of sediment yield provide information on the net loss of sediment from an area (Cai, 2001; Tang et al., 1993), they cannot be directly converted into (top-) soil erosion rates as other erosion processes may significantly contribute to sediment mobilization and mobilized sediments may be stored on land rather than being exported by the river. Topsoil erosion rates may also be estimated using models, such as the USLE model (Wischmeier and Smith, 1978) or its upgraded version, the RUSLE (Renard et al., 1997). The (R)USLE is a relatively simple multiplicative model that has been extensively calibrated and validated for the prediction of topsoil erosion by water (rill and inter-rill erosion) on cropland in the USA. Current (R)USLE estimates of topsoil erosion on the CLP vary between 0.95 and $4.32 \mathrm{Gt} \mathrm{yr}^{-1}$, a wide range reflecting the uncertainty on these estimates (Table 2). Furthermore, these values are mostly significantly larger than the total sediment yield of the CLP before conservation programs were implemented and reservoirs were installed (ca. $1.37 \mathrm{Gt} \mathrm{yr}^{-1}$, Miao et al., 2010). However, a dense network of active gullies is present in large areas of the CLP (Cai, 2001) and landslides due to earthquakes or heavy rainfall mobilize large amounts of sediment (Zhang and Wang, 2007). It is unlikely that the total contribution of these processes to sediment export would be negligible in comparison to the amount of soil mobilized by topsoil erosion. This raises the question whether the true rate of topsoil erosion is even within the broad range of estimates that has been published.

Clearly, the large uncertainties on current topsoil erosion rates prevent a correct assessment of the impact of topsoil erosion on $\mathrm{C}$ cycling and soil fertility on the CLP. However, an important data source that may allow to address these uncertainties has hitherto been left untapped. On the CLP, numerous field studies on erosion have been carried out. Many of these studies were carried out using erosion plots and therefore measured topsoil erosion by sheet and rill erosion. Other studies assessed erosion rates at the small catchment scale, where measured sediment fluxes are the result of both topsoil erosion and gully erosion. 


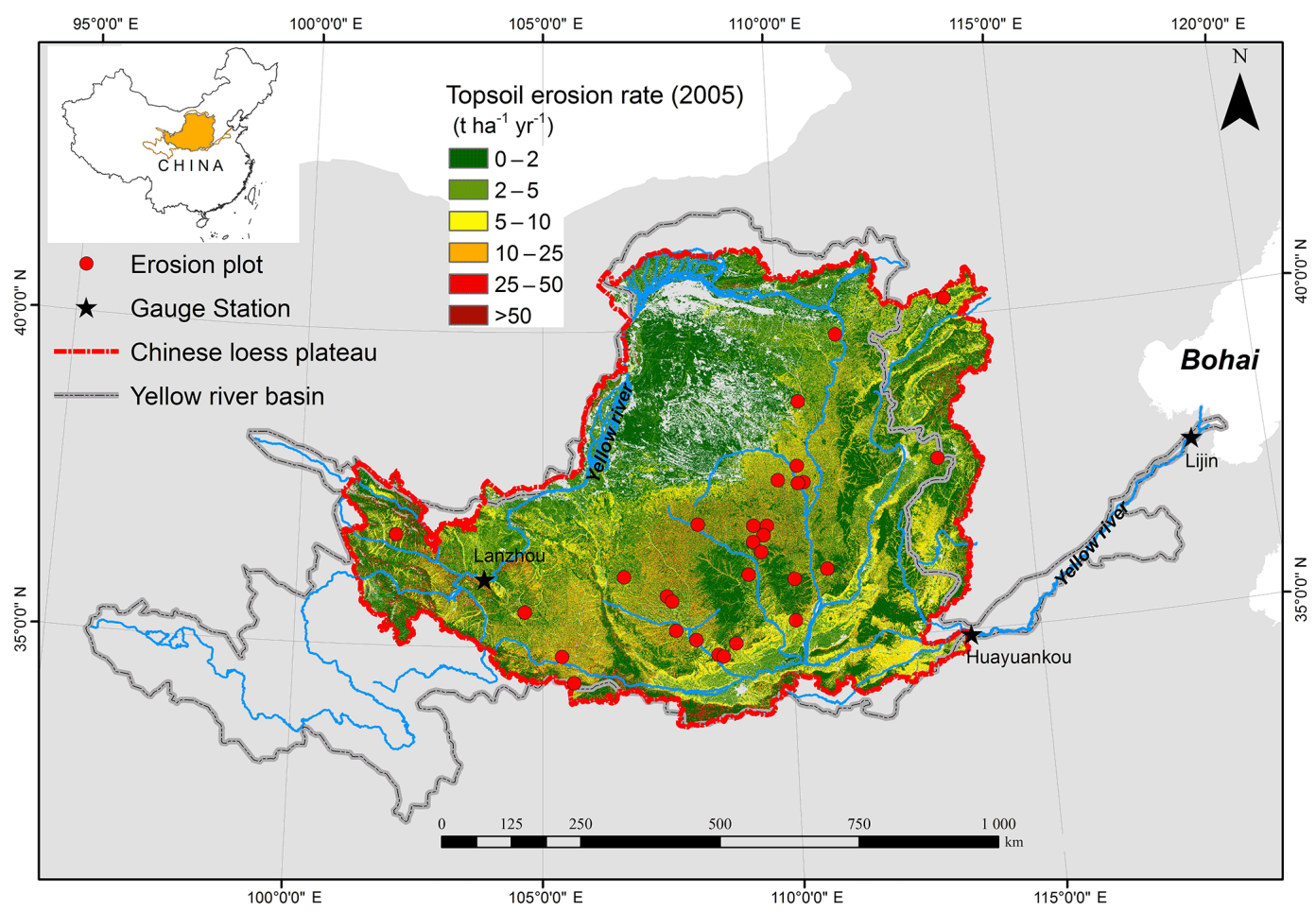

Figure 1. Topsoil erosion map of the Chinese loess plateau calculated from our model (Eq. 2) with an indication of the location of the erosion plots used in this study.

In this paper we used the results of these field observations to develop models that, after validation, allowed to calculate topsoil erosion and gully erosion rates on the CLP before and after conservation programs were implemented. We assessed how conservation programs have affected sediment mobilization by these processes as well as sediment storage and transport. This allowed us (i) to develop sediment budgets for the CLP before and after the implementation of conservation programs and (ii) to more accurately assess the amount of SOC and nutrients that is mobilized by erosion on the CLP, so that the magnitude of the erosion-induced carbon sink could be constrained and the importance of erosioninduced nutrient losses could be quantified. Finally, we evaluated how these erosion-induced nutrient losses may have affected agricultural production under past and present conditions.

\section{Materials and methods}

\subsection{Materials}

Erosion plot database (EPD). We compiled a large data set of erosion rates measured on erosion plots from scientific papers, books and reports (Supplement 1). Only measurements conducted for at least 1 year on bounded erosion plots with a minimum plot length of $3 \mathrm{~m}$ with a specific land use type under natural rainfall were retained. Plots on which soil and water conservation measures were tested were not considered as these are not representative for standard agricultural practices. The final database consisted of data for 306 erosion plots spread all over the CLP (Fig. 1), on which measurements were carried out for a total of 1357 plot years (Supplement 1).

Landscape characterization. 1000 points (GEps), randomly distributed and covered on the whole CLP, were selected using ArcGIS 10.1 software (Supplement 1). The points were loaded into Google ${ }^{\circledR}$ Earth software and for each point the land use type was determined visually using four classes: (i) forest, (ii) grassland, (iii) farmland and (iv) "other" (built-up, desert or barren and water body). The topography was also subdivided into four categories: (i) flat, (ii) hilly, (iii) gullied land and (iv) other if the topography type could not be well defined. Desert areas were classified separately. When farmland was present, we registered whether or not the farmland was terraced and determined the maximum field length in the downslope direction. The proportion of gullied areas for the whole CLP $\left(A_{\mathrm{g}}\right)$ was estimated as the ratio of the number of GEps classified as "gullied land" to the total number of points. The proportion of terraced land $\left(T_{\mathrm{P}}\right)$ as well as the average field slope length for terraced $\left(\lambda_{\mathrm{T}}\right)$ and sloping, non-terraced land $\left(\lambda_{\mathrm{S}}\right)$ was calculated for $5^{\circ}$ slope intervals.

Land use. Two land use data sets were provided by the Resources and Environmental Centre of the Institute of Ge- 


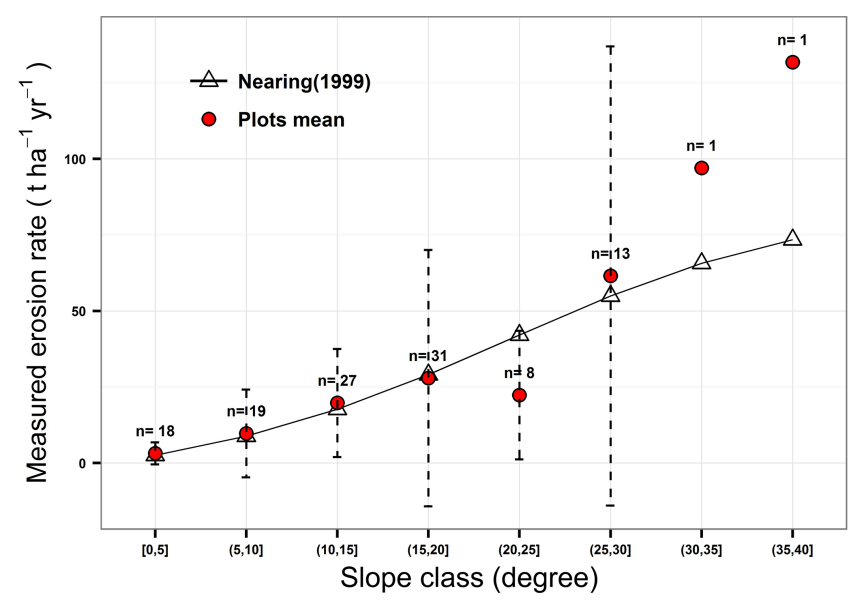

Figure 2. Weighted mean and standard deviation of the soil topsoil erosion rate for different slope classes of arable land on the CLP as derived from the erosion plot database. (Relative) variations predicted using the model of Nearing (1999) are also indicated. The Nearing model excellently predicts relative variations in erosion rates up to a slope of $30^{\circ}$ and was therefore used in this study. Comparison of model predictions and observations at higher slope gradients is not relevant due to the small number of observations.

ographical Sciences and Natural Resources Research, Chinese Academic of Sciences (http://www.geodata.cn/). The first data set describes land use on the CLP during the 1980s (exact date not known) while the second data set describes land use in 2005. Both land use data sets were in raster format with a resolution of $100 \mathrm{~m}$.

Slope gradient. We first constructed a DEM with a $100 \mathrm{~m}$ resolution from a corrected SRTM data set (90 $\mathrm{m}$ resolution) which was provided by the Environmental and Ecological Science Data Centre for West China, National Science Foundation of China (http://westdc.westgis.ac.cn/). Slope calculations were corrected for resolution effects using the procedures developed by Van Oost et al. (2007).

\subsection{Estimation of average topsoil erosion rate (TER)}

Erosion plot rates cannot be directly extrapolated to large areas: erosion plots tend to be located in areas where erosion rates are high and have dimensions that are smaller than that of a typical field (Cerdan et al., 2010). Thus, the dependency of erosion rates on topography (slope gradient and length) as well as land use need to be accounted for when estimating area-wide topsoil erosion rates.

On farmland erosion plots, a strong correlation was found between TER and slope gradient and slope length (Figs. 2 and 3, Table 1). Such consistent relationships were not present for plots with other land uses (Fig. 4, Table 1). Surface runoff on grassland and on permanently vegetated land (forest and shrub land) is most often discontinuous with patches generating runoff that subsequently infiltrates at other locations on the slope: hence, the erosive power of

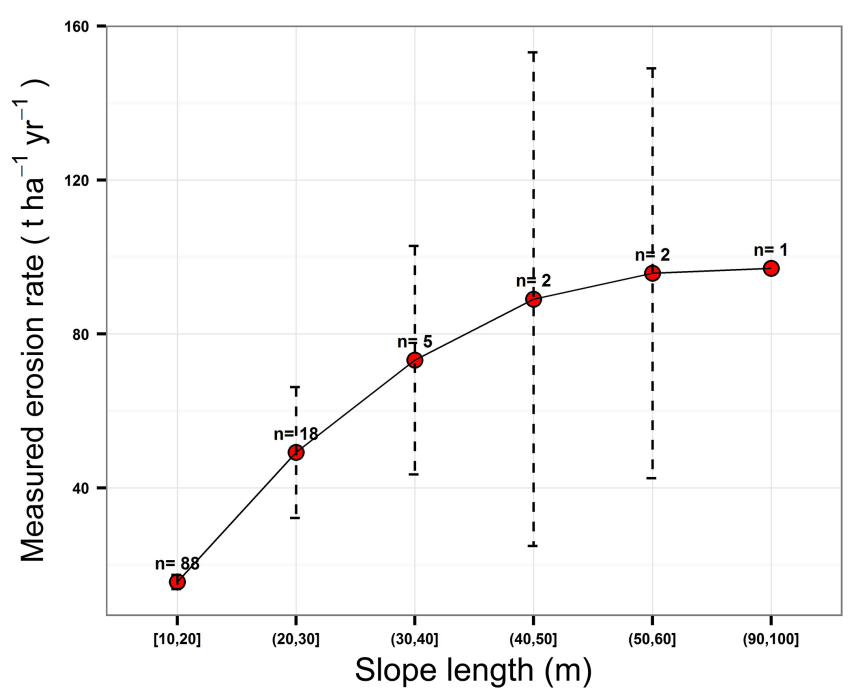

Figure 3. Topsoil erosion rate (weighted mean and standard deviation) vs. slope length for erosion plots under arable land on the CLP.

overland flow does not increase systematically in the downslope direction and erosion rates do not increase with slope length (Cammeraat, 2002; Cerdan et al., 2004). The absence of a relationship between slope gradient and TER for plots under permanent vegetation may be due to the fact that erosion under low runoff conditions is limited by the amount of material that is dislodged by raindrop impact. The latter process does not show a strong slope dependency (Torri and Poesen, 1992).

As a relationship between erosion rates and topography was only present for farmland, different strategies were employed to estimate the mean TER for farmland in comparison to other land uses. We found that Nearing's model (Nearing, 1997) described the relationship between erosion rate and slope gradient on farmland very well (Fig. 2). As this model was already extensively tested using data from the CLP (Nearing, 1997) and is consistent with earlier studies we used it to normalize observed erosion rates with respect to slope gradient.

$\mathrm{TER}^{\prime}=a \times\left(-1.5+\frac{17}{1+e^{2.3-6.1 \sin \theta}}\right)$,

where TER' is the slope-corrected TER for farmland $\left(\mathrm{tha}^{-1} \mathrm{yr}^{-1}\right) ; a$ is a scaling factor representing the comprehensive effect of $R$ (rainfall erodibility) and $K$ (soil erodibility) on the TER. The value of $a$ was determined through regression analysis (see below).

The TER measured on farmland was also dependent on slope length (Fig. 3, Table 1). We assumed that erosion rate was proportional to the square root of slope length, which is consistent with earlier research (Liu et al., 2000; Wischmeier and Smith, 1978). 

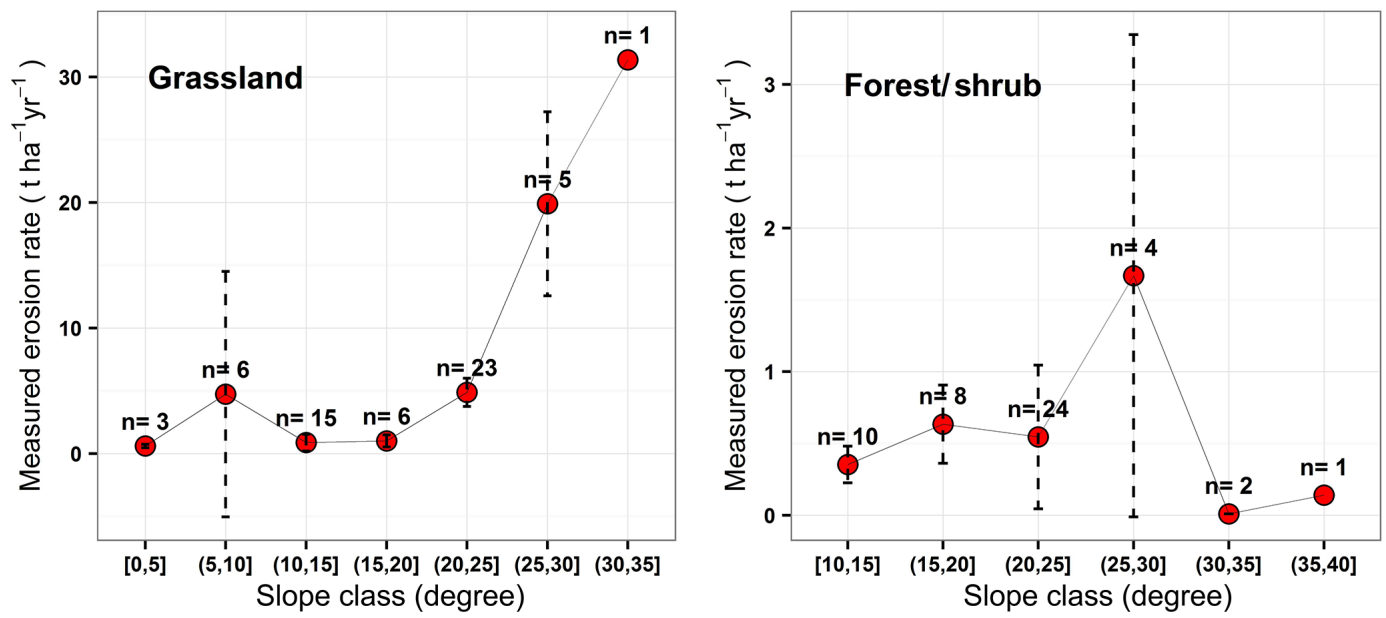

Figure 4. Weighted mean soil erosion rate under grassland and permanent vegetation (PV) for different slope classes: erosion rates were calculated using the data from our erosion plot database. Slope does not have a statistically significant effect on topsoil erosion rates on land under permanent woody vegetation. On grassland, a slope effect may be present, but only for slopes exceeding $25^{\circ}$ : however, more data are needed to confirm this.

Table 1. Correlation (Pearson $r^{2}$ ) between topsoil erosion rate and topography (slope gradient and slope length) under different land uses: no significant relationships were found for plots with a permanent vegetation cover. The effect of slope is significant on grassland but this is due to high values observed on slopes exceeding $25^{\circ}$, for which only a few data points are available: no significant slope effect is present for lower slope gradients (Fig. 4).

\begin{tabular}{lrrrrr}
\hline & $\begin{array}{r}\text { Bare } \\
(n=14)\end{array}$ & $\begin{array}{r}\text { Fallow } \\
(n=16)\end{array}$ & $\begin{array}{r}\text { Farmland } \\
(n=120)\end{array}$ & $\begin{array}{r}\text { Grassland } \\
(n=90)\end{array}$ & $\begin{array}{r}\text { Vegetation cover } \\
(n=66)\end{array}$ \\
\hline Slope degree & $0.64^{*}$ & $0.84^{* * *}$ & $0.49^{* * *}$ & $0.19^{*}$ & $\mathrm{~ns}$ \\
Slope length & $\mathrm{ns}$ & $\mathrm{ns}$ & $0.37^{* * *}$ & $\mathrm{~ns}$ & $\mathrm{~ns}$ \\
\hline$* p<0.05,{ }^{* * *} p<0.001$ ns: no significance. & & &
\end{tabular}

Finally, calculation of the TER needs to account for the presence of terraces. First, we calculated the probability of a slope being terraced $\left(T_{\mathrm{P}}\right)$ using an empirical relationship between slope gradient and the proportion of the farmland that was terraced (Fig. 5). Next, we calculated the Terrace efficiency $\left(T_{\mathrm{E}}\right)$, i.e. the reduction in TER that is achieved by installing terraces on a slope with arable land. We found 16 erosion plot studies evaluating the effect of terracing on erosion rates on the CLP using a paired sample design (i.e. topographyCLP using a paired sample design, crops and soil conservation measures other than terraces were similar on the terraced and non-terraced plots) (Supplement Table S1). The terrace efficiency factor, $T_{\mathrm{E}}$, was calculated as the ratio between the erosion rate observed on the terraced and non-terraced plots. The mean $T_{\mathrm{E}}$, weighted by the number of plot years, was $0.20 \pm 0.19$ indicating that the TER on terraced farmland was, on average, only $20 \%$ of that occurring on non-terraced farmland. Finally we calculated the average TER for a pixel under arable land use as follows:

$\mathrm{TER}=\mathrm{TER}^{\prime} \times\left[\left(\frac{\lambda_{\mathrm{T}}}{22}\right)^{0.5} \times T_{\mathrm{P}} \times T_{\mathrm{E}}+\left(1-T_{\mathrm{P}}\right) \times\left(\frac{\lambda_{\mathrm{S}}}{22}\right)^{0.5}\right]$, where $T_{\mathrm{P}}$ is probability of terracing for the slope class to which the pixel belongs (Fig. 5), while $\lambda_{\mathrm{T}}$ and $\lambda_{\mathrm{S}}$ are the average slope lengths for terraced and non-terraced farmland for this particular slope class (Fig. 6) and $T_{\mathrm{E}}$ is the terrace efficiency (see above).

We did find a significant positive relationship between rainfall erosivity on the one hand and normalized erosion rates on farmland on the other hand but the explained variance was very small $(3 \%)$. Therefore, we did not include rainfall erosivity in our model. The low explanatory value of rainfall erosivity is probably explained by the fact that in drier conditions (with lower rainfall erosivity) soil cover by vegetation will also be lower: a low erosivity is then compensated for by a high vegetation cover factor.

As we did not find any relationship between topography and erosion rates on grassland and land under permanent vegetation (Fig. 4, Table 1), we estimated erosion rates for pixels under these land uses by simply taking the average erosion rate observed on erosion plots with the same land use. 
Table 2. Estimates of total topsoil erosion $\left(\mathrm{Gt} \mathrm{yr}^{-1}\right)$ and average TER $\left(\mathrm{tha}^{-1} \mathrm{yr}^{-1}\right)$ on the CLP. Note that estimates refer to the entire surface area of the CLP (all land uses).

\begin{tabular}{lrrrl}
\hline Reference & $\begin{array}{r}\text { Area } \\
\left(\mathrm{km}^{-2}\right)\end{array}$ & $\begin{array}{r}\text { Total topsoil } \\
\text { erosion }\left(\mathrm{Gt} \mathrm{yr}^{-1}\right)\end{array}$ & $\begin{array}{r}\text { Average TER } \\
\left(\mathrm{tha}^{-1} \mathrm{yr}^{-1}\right)\end{array}$ & Method \\
\hline Fu et al. (2011) & 620000 & 1.51 & 23.99 & RUSLE \\
Sun et al. (2013) & 620000 & 0.95 & 15.20 & RUSLE \\
Schnitzer et al. (2013)-RUSLE1 & 900000 & 4.32 & 48.00 & RUSLE \\
Schnitzer et al. (2013)-RUSLE2 & 900000 & 1.45 & 16.11 & RUSLE \\
Ran et al. (2014) & 750000 & 2.2 & 29.00 & Literature review \\
\hline This study & 620000 & $0.30 \pm 0.08$ & $5.41 \pm 1.35$ & \\
\hline
\end{tabular}

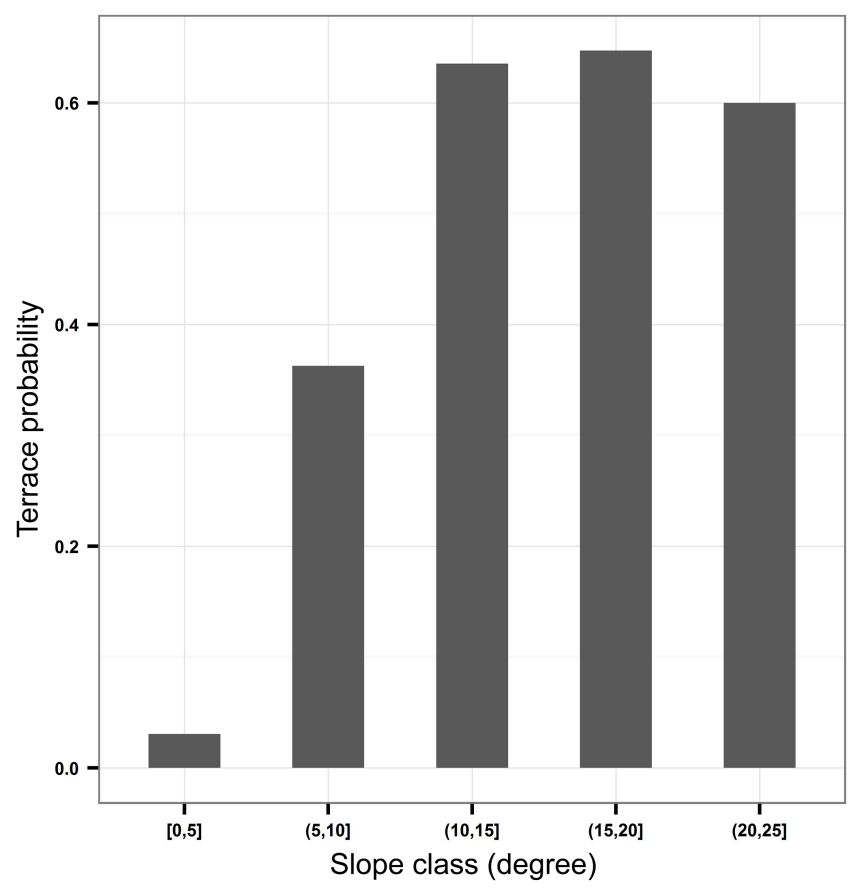

Figure 5. Proportion of farmland on the CLP that is terraced for different slope classes (GEps observations). The probability that land is terraced strongly increases up to a slope gradient of ca. $10^{\circ}$ after which it remains more or less constant up to a slope gradient of ca. $25^{\circ}$. Very steep slopes are somewhat less frequently terraced, possibly because the marginal agricultural return does not warrant the terracing effort.

\subsection{Uncertainty analysis}

Our estimates of TER are subject to important uncertainties. The most important of those are the uncertainties (i) on the effects of rainfall erosivity, soil erodibility and crop type (integrated in the factor $a$ ), (ii) on the effectiveness of terracing ( $\left.T_{\mathrm{E}}\right)$, (iii) on the proportion of terracing $\left(T_{\mathrm{P}}\right)$, as well as uncertainty (iv) on the average field length under terraced $\left(\lambda_{T}\right)$, and non-terraced conditions $\left(\lambda_{\mathrm{s}}\right)$. We quantified the resulting overall uncertainty using a Monte-Carlo analysis whereby 6000 independent calculations were run, randomly sampling

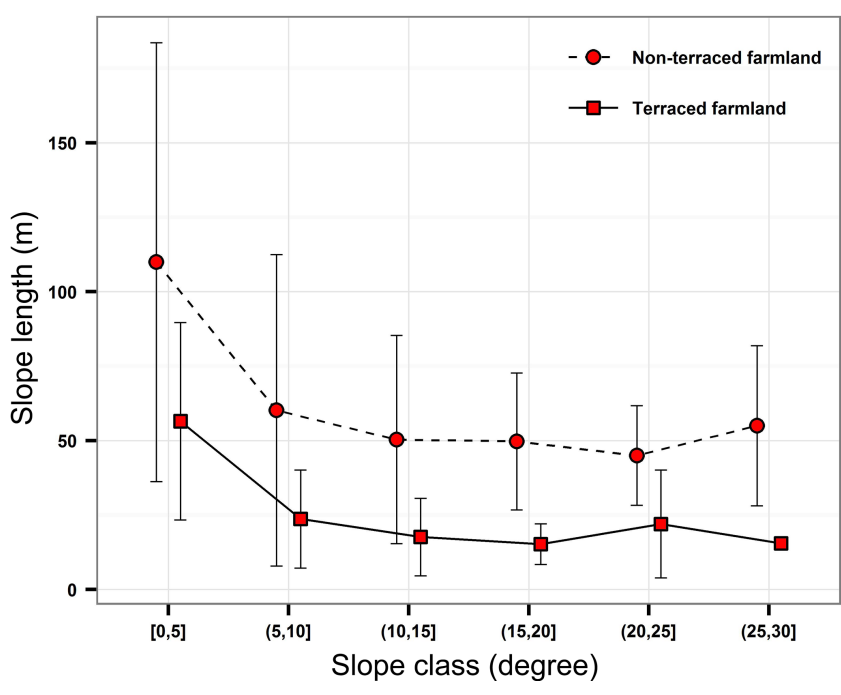

Figure 6. Measured mean slope length for terraced and nonterraced farmland in different slope classes on the CLP (GEps observations). Field sizes and hence slope length are clearly larger on gentle slopes.

each of the aforementioned variables, assuming a normal distribution described by its mean value and the standard deviation of this mean. Standard deviations of the mean value could be derived from the sample data sets from $T_{\mathrm{E}}, T_{\mathrm{P}}, \lambda_{\mathrm{T}}$ and $\lambda_{\mathrm{s}}$. The standard error of the mean for $a$ was quantified by perturbing the observed erosion rates in each slope class by adding an error term to the observed mean value of the TER for each slope class and subsequently estimating $a$ using Eq. (1). The error term for TER was randomly drawn from a normal distribution with a mean value of zero and a standard deviation equal to the standard deviation of the mean TER value observed for each slope class (visualized by the error bars on Fig. 2). This procedure was also repeated 6000 times so that the mean and the standard error of $a$ could be reliably calculated. 


\subsection{Validation of the empirical topsoil erosion model}

We tested the performance of our topsoil erosion model (Eq. 2) by comparing model estimates with topsoil erosion rates (TER) derived from ${ }^{137} \mathrm{Cs}$ measurements carried out on the CLP. The latter allow in principle to estimate the overall soil loss over a period of ca. 40 years (Walling and Quine, 1992). We only selected studies for which detailed information on the field sites studied (size of the field, land use, topography) was available. Furthermore, it had to be possible to separate the effects of water and tillage erosion if the latter was important (Govers et al., 1996). We found studies on 44 slopes for which these conditions were met (Table S2). If estimates of water erosion were reported in the study, the reported value was directly used. If only ${ }^{137} \mathrm{Cs}$ inventories were provided, the TER was calculated by a simple model relating ${ }^{137}$ Cs depletion to soil loss (Zhang et al., 2008a; Eq. 2):

$R_{\mathrm{e}}=H \times \rho_{\mathrm{b}} \times\left(1-\left(\frac{x}{x_{\mathrm{ref}}}\right)^{\frac{1}{n-1963}}\right)$

where $R_{\mathrm{e}}$ is the estimated soil erosion rate $\left(\mathrm{t} \mathrm{km}^{-2} \mathrm{yr}^{-1}\right)$, $H$ is the depth of the plough layer $(0.15 \mathrm{~m}$ or using a reported value), $\rho_{\mathrm{b}}$ is the specific density of the plough layer ( $1450 \mathrm{~kg} \mathrm{~m}^{-3}$ or using a reported value), $x$ is the measured mean ${ }^{137} \mathrm{Cs}$ inventory of the slope $\left(\mathrm{Bq} \mathrm{m}^{-2}\right), x_{\text {ref }}$ is the locally reference ${ }^{137} \mathrm{Cs}$ inventory $\left(\mathrm{Bq} \mathrm{m}^{-2}\right)$ and $n$ is the year of sampling.

The accuracy of the model estimates was calculated using the relative root mean square error (RRMSE) (Van Rompaey et al., 2001; Eq. 3):

$\operatorname{RRMSE}=\frac{\sqrt{\frac{1}{n} \sum_{i=1}^{n}\left(M_{i}-P_{i}\right)^{2}}}{\frac{1}{n} \sum_{i=1}^{n} M_{i}}$,

where $M_{i}$ is the measured TER derived from ${ }^{137} \mathrm{Cs}$ inventory, $P_{i}$ is the predicted TER from our model (Eq. 2) and $\mathrm{n}$ is the number of observations. Figure 7 demonstrates that agreement between measured and predicted TER is good: the RRMSE is 0.56 and $77 \%$ of the predicted values are within a factor 0.5 to 2 of the measured values. Part of the unexplained variance is due to the fact that soil erosion at the plot scales is characterized by a strong variability (Nearing et al., 1999; Eq. 4). Furthermore, soil erosion may be expected to be affected by factors such as local rainfall characteristics, crop type and specific soil properties at the measurement site, which were not included in our model. Finally, the accuracy of ${ }^{137} \mathrm{Cs}$ inventories is affected by factors such as detector sensitivity and small-scale spatial variability of ${ }^{137} \mathrm{Cs}$ inventories (Parsons and Foster, 2011).

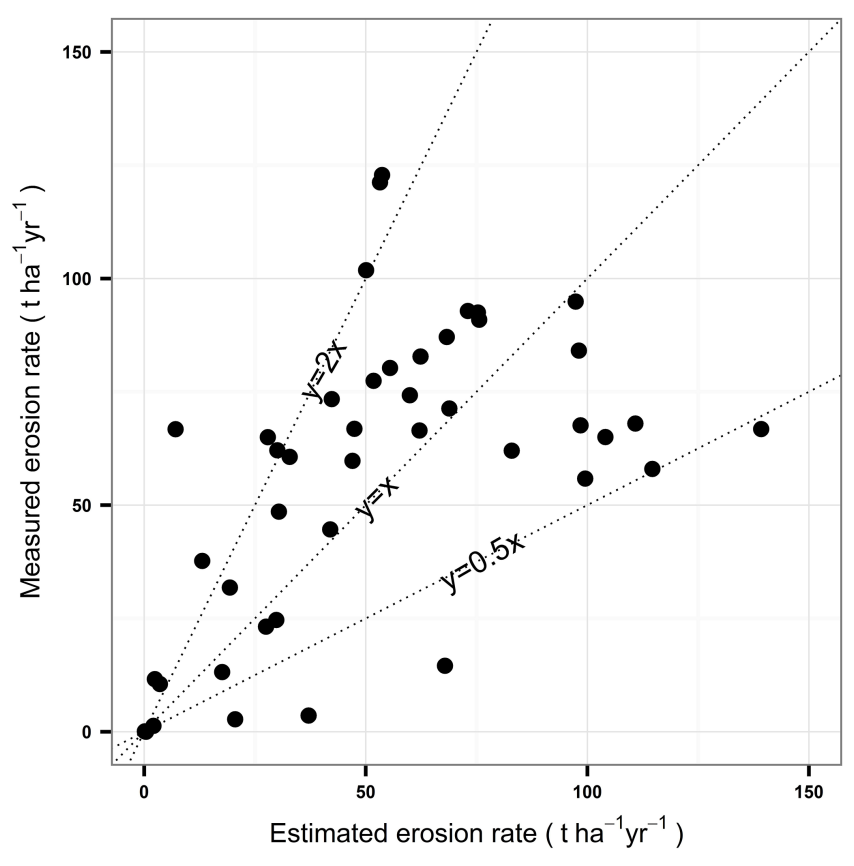

Figure 7. Erosion rates estimated using our empirical model (Eq. 2) vs. measured erosion rates on arable land. Measured erosion rates were calculated from ${ }^{137} \mathrm{Cs}$ inventories (Eq. 3).

\subsection{Estimation of total sediment mobilization}

We estimated total sediment mobilization at two moments in time: the first moment is 1950 . We assumed that, at this moment, no terraces or other soil conservation measures had been implemented on the CLP (i.e. $T_{\mathrm{P}}=0$ ). This assumption is obviously a simplification: it may be expected that some measures to protect the cropland were in place prior to 1950 . However, the vast majority of the terraces present on the CLP have been constructed after 1950 when terrace implementation was stimulated through massive government programs (Chen et al., 2007; Zhang et al., 2008b). Furthermore, we assumed that the land use in the 1980s was similar to that in the period 1950-1970. Given the fact that during the entire 1950-1980 period the emphasis of government efforts was clearly on the increase of agricultural production this assumption is reasonable as was also shown by $\mathrm{Fu}$ et al. (2006) for a small catchment of the CLP. The second moment is 2005. We assumed that the occurrence of terraces on the CLP was stable between 2005 and 2010, which is the date of the imagery we used to derive terrace density (see Sect. 2.1). Again, this is reasonable given that terrace construction on the CLP almost stopped after 1990 (Zhang et al., 2008b).

The total amount of sediment mobilized by topsoil erosion in 1950 and 2005 was then estimated by aggregating the topsoil erosion amount estimated for individual pixels under the assumptions described above. Clearly our calculations do not reflect actual erosion amounts in those years. Rather they 
should be considered as an estimation of the average, longterm erosion rates that would occur if climate, land use and soil conservation measures would be stable for an extended time period.

\subsection{The contribution of gully erosion}

${ }^{137} \mathrm{Cs}$ is a soil erosion tracer that is in principle only present in the topsoil to which it was delivered by rainfall and dry deposition after the open air nuclear experiments between 1950 and 1970 (Walling and Quine, 1992). Assuming that, in a catchment where gullying does occur, the ${ }^{137} \mathrm{Cs}$ concentration in the topsoil of the non-gullied areas, in the sediments coming from gullied areas, and in sediment being deposited in colluvial/alluvial environments downstream of the erosion areas is known, the contribution of gully erosion to total catchment erosion can be estimated as

$\mathrm{SC}_{\mathrm{g}}=\frac{\mathrm{Cs}_{\mathrm{h}}-\mathrm{Cs}_{\mathrm{d}}}{\mathrm{Cs}_{\mathrm{h}}-\mathrm{Cs}_{\mathrm{g}}}$,

where $\mathrm{SC}_{\mathrm{g}}$ is the sediment contribution of gully areas (\%) and $\mathrm{Cs}_{\mathrm{g}}, \mathrm{Cs}_{\mathrm{h}}$ and $C s_{\mathrm{d}}$ are the average ${ }^{137} \mathrm{Cs}$ concentrations in sediments from gullied, non-gullied and depositional areas $\left(\mathrm{Bq} \mathrm{kg}^{-1}\right)$, respectively.

We found 11 studies on relatively small catchments for which such data were available (Table S3). Using these data as well as the relative areal extent of gullies $\left(\mathrm{CA}_{\mathrm{g}}, \%\right)$ in each of these catchments we were therefore able to calculate the ratio between the topsoil erosion rate on hilly arable land and the gully erosion rate $\left(E_{\mathrm{g} / \mathrm{h}}\right)$ for each catchment.

$E_{\mathrm{g} / \mathrm{h}}=\frac{\mathrm{SC}_{\mathrm{g}}\left(1-\mathrm{CA}_{\mathrm{g}}\right)}{\mathrm{CA}_{\mathrm{g}}\left(1-\mathrm{SC}_{\mathrm{g}}\right)}$

In order to estimate the contribution of gullies to total sediment mobilization on the CLP we first calculated the average TER for hilly areas $\left(E_{\mathrm{h}}, \mathrm{tha}^{-1} \mathrm{yr}^{-1}\right)$. The proportion of gully areas for the whole CLP $\left(A_{\mathrm{g}}\right)$ was calculated based on the information obtained from the GEps. Finally, the total amount of sediment mobilized in these gullied areas was estimated as

$\mathrm{SY}_{\mathrm{g}}=E_{\mathrm{g} / \mathrm{h}} \times E_{\mathrm{h}} \times A_{\mathrm{g}} \times \mathrm{TA}_{\mathrm{clp}}$,

where $\mathrm{SY}_{\mathrm{g}}$ is the amount of sediment mobilized by gully erosion and $\mathrm{TA}_{\mathrm{clp}}$ is the total area of CLP $\left(620000 \mathrm{~km}^{2}\right)$.

\subsection{The contribution of landslides}

To the best of our knowledge, no detailed landslide inventory of the CLP exists. We used the data provided by Derbyshire et al. (2000) to estimate the number of major landslides occurring per year and combined this with a conservative estimate of mean volume of a major landslide $\left(3 \pm 2.14 \times 10^{6} \mathrm{~m}^{2}\right.$, Zhang and Wang, 2007) to make a preliminary estimate of the mean sediment flux that is delivered

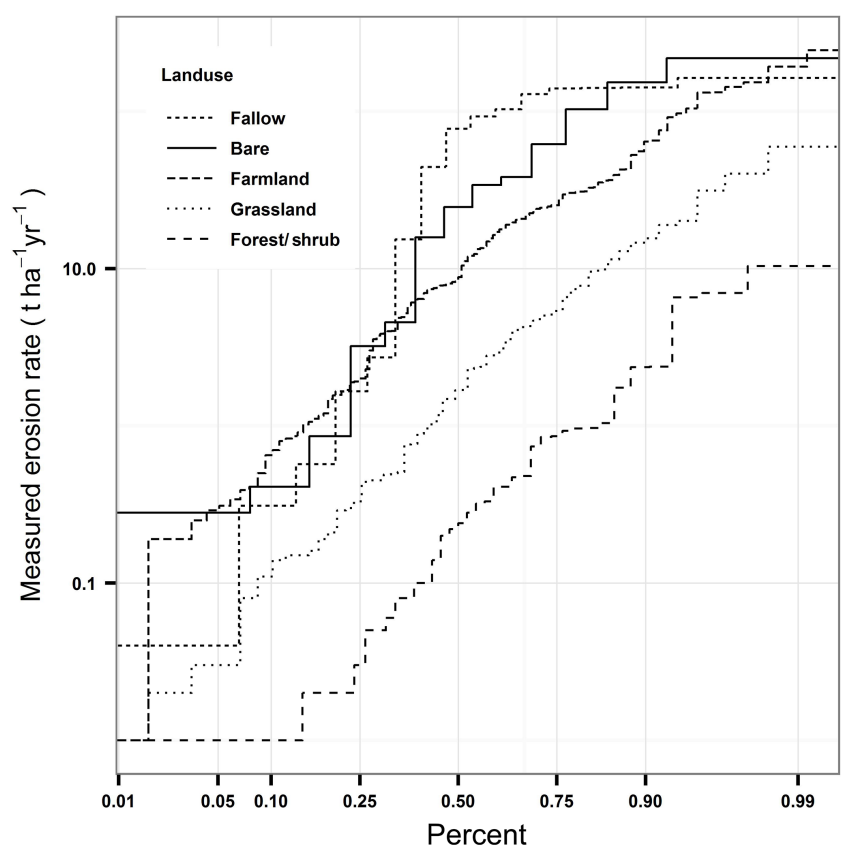

Figure 8. Cumulative distribution of measured erosion rates measured on erosion plots under different land uses ( $x$ axis: cumulative fraction of plots for which erosion rate is lower than indicate value). Erosion rates under permanent woody vegetation are 1-2 orders of magnitude lower than erosion rates under arable land use.

to the river network by landslides. It is evident that the uncertainty on our estimate is large and that landslide events will be highly episodic, triggered by major rainfall events and/or earthquakes but the necessary data to assess this temporal variability are at present not available.

\section{Results and discussion}

\subsection{Topsoil erosion}

The analysis of the plot data confirmed the importance of land use and/or vegetation cover for topsoil erosion: the average topsoil erosion rate (TER) measured on plots with permanent woody vegetation (shrub or forest) was $0.70 \pm 0.28 \mathrm{tha}^{-1} \mathrm{yr}^{-1}(n=66)$ while the average TER on grassland plots was $5.51 \pm 1.36 \mathrm{tha}^{-1} \mathrm{yr}^{-1}(n=90)$. The TER measured under forest is considerably lower than the average TER observed on arable farmland plots (23.61 $\left.\pm 3.69 \mathrm{tha}^{-1} \mathrm{yr}^{-1}, n=120\right)$, confirming that conversion of forest to arable land may increase the TER by up to 2 orders of magnitude (Montgomery, 2007). TER on bare land plots was, on average $45.27 \pm 19.17 \mathrm{tha}^{-1} \mathrm{yr}^{-1}(n=14)$, which is about twice as high as that observed on arable land (Fig. 8).

Plot erosion rates were extrapolated to the whole of the CLP using the procedures described above (Sect. 2.2). The estimated average TER under 2005 conditions was 
$9.74 \pm 3.12 \mathrm{tha}^{-1} \mathrm{yr}^{-1}$ for farmland; $3.78 \pm 1.63 \mathrm{tha}^{-1} \mathrm{yr}^{-1}$ for grassland and $0.53 \pm 0.15 \mathrm{tha}^{-1} \mathrm{yr}^{-1}$ for land with permanent woody vegetation. The calculated overall average TER was $5.41 \pm 1.35 \mathrm{tha}^{-1} \mathrm{yr}^{-1}$ for the whole CLP and the total amount of sediment mobilized by topsoil erosion was estimated at $0.30 \pm 0.08 \mathrm{Gt}$, with $0.198 \pm 0.062 \mathrm{Gt}$ coming from arable land and $0.098 \pm 0.043 \mathrm{Gt}$ coming from grassland. About $57.0 \pm 11.2 \%$ of the total amount of topsoil that is lost due to erosion comes from non-terraced arable land which occupies $61.30 \%$ of the total area of arable land. Terraced arable land contributes ca. $8.8 \pm 3.5 \%$; ca. $32.6 \pm 11.6 \%$ comes from grassland and the reminder $1.6 \pm 0.7 \%$ comes from land with permanent vegetation (Fig. 1).

Under 1950 conditions, the average estimated TER on farmland was almost twice as high $\left(19.3 \pm 6.18 \mathrm{tha}^{-1} \mathrm{yr}^{-1}\right)$. This resulted in a total amount of topsoil mobilization of $0.40 \pm 0.13 \mathrm{Gt}$. An additional $0.10 \pm 0.04 \mathrm{Gt}$ was mobilized on grassland and land under permanent vegetation, resulting in an overall total of $0.51 \pm 0.13 \mathrm{Gt}$ of topsoil erosion.

Our estimates of topsoil erosion under 2005 conditions are 3 to 9 times lower than the estimates reported in recent studies (Table 2). This discrepancy far exceeds the uncertainties associated with our estimates. Several reasons may explain why previous estimates of topsoil erosion were too high but two factors appear to be of particular importance. First, soil erodibility is often strongly overestimated by applying a model for soil erodibility prediction that is not applicable to Chinese loess soils (Table S4 and Supplement Discussion). Second, the procedures to estimate slope length at the landscape scale tend to ignore the effects of landscape structure and field borders in particular. Field borders tend to reduce effective slope lengths and hence erosion rates (Van Oost et al., 2000). Ignoring the landscape structure leads to greatly exaggerated estimates of effective slope length and hence also of topsoil erosion rates (see Supplement for a more detailed discussion).

\subsection{Gully erosion and landslides}

We estimated the relative contribution of gullies to sediment mobilization in seven agricultural catchments and used the data from four other studies reporting the contribution of gully erosion using the ${ }^{137} \mathrm{Cs}$ content of sediments in gully, inter-gully areas and reservoirs and retention structures downstream of small, gullied catchments (Supplement Table 4). Our calculations showed that gully erosion mobilized, on average, $2.60 \pm 1.48$ times more sediment than sheet and rill erosion in these catchments, confirming the importance of gullies as a sediment source (Table S4). Based on our GEps, we estimated that ca. $13.2 \pm 2.0 \%$ of total area of the CLP is covered by gullied land, an estimate which is comparable to that of Sun et al. (2014) who estimated that $14.4 \%$ of the CLP is subject to intense gullying. Using our model (Eq. 2) we estimated the average TER for arable land in the hilly areas of the CLP at $10.78 \pm 15.27 \mathrm{tha}^{-1} \mathrm{yr}^{-1}$ and assumed this value to be representative for the arable land in the catchments where the relative contribution of gully erosion was assessed. Combining these values using Eq. (7), we estimated that gullies mobilized $0.23 \pm 0.28 \mathrm{Gt} \mathrm{yr}^{-1}$ of sediments under 2005 conditions (Sect. 2.6). As is the case for topsoil erosion, gully erosion was reduced by conservation programs: concurrently with terracing, check dams were installed on gully floors, thereby stabilizing their base level (Xu et al., 2004). We assumed that the decrease in gully erosion rates was proportional to the decrease in TER. Therefore we estimate that under 1950 conditions ca. $0.38 \pm 0.46 \mathrm{Gt} \mathrm{yr}^{-1}$ of sediments was mobilized by gully erosion.

More than 40000 landslides have been identified on the CLP (Derbyshire et al., 2000). Derbyshire et al. (2000) report that ca. 1000 "large" landslides occurred on the CLP between 1965 and 1979. Assuming an average volume of 3 million $\mathrm{m}^{3}$ for a large landslide, the volume of sediment that is annually mobilized by these landslides can be conservatively estimated as ca. $0.28 \pm 0.23 \mathrm{Gt}$ (Sect. 2.7). This estimate does not include the contribution of seismic events such as the Haiyuan earthquake (1928), which generated over 1000 landslides on its own (W. Li et al., 2015). The impact of conservation measures on landslides is ambiguous. While the reshaping of slopes by terracing may in principle increase their stability, terracing also facilitates irrigation and may therefore increase the landslide risk (Meng and Derbyshire, 1998). At the same time, the stabilization of the base level by check dams reduced the risk of slope failure. We therefore assumed that the landslide risk was not affected by conservation programs and sediment mobilization by landslides was, on average, constant over time.

\subsection{The impact of conservation programs on sediment mobilization}

Our analysis clearly shows that sediment mobilization was significantly reduced (by ca. $40 \%$ for topsoil erosion) by the conservation programs that the Chinese government started to implement from 1950 onwards. This reduction is mainly due to the implementation structural measures such as check dams and terraces. The effect of land use changes induced by regreening programs was still small under 2005 conditions, leading to reduction of topsoil erosion on agricultural land by ca. $0.01 \mathrm{Gt}$ in comparison to 1950 . As the area covered by these conservation programs continues to increase, their effect on erosion reduction will also increase (Fu et al., 2011).

\subsection{Sediment budget}

The average sediment export from the CLP measured at Huayunkou station (Fig. 1), which is located on the Yellow River just downstream of the CLP was, on average, ca. $1.37 \mathrm{Gt} \mathrm{yr}^{-1}$ between 1950 and 1975 (Ministry of Water Resources of China, 2011). Other long-term estimates con- 


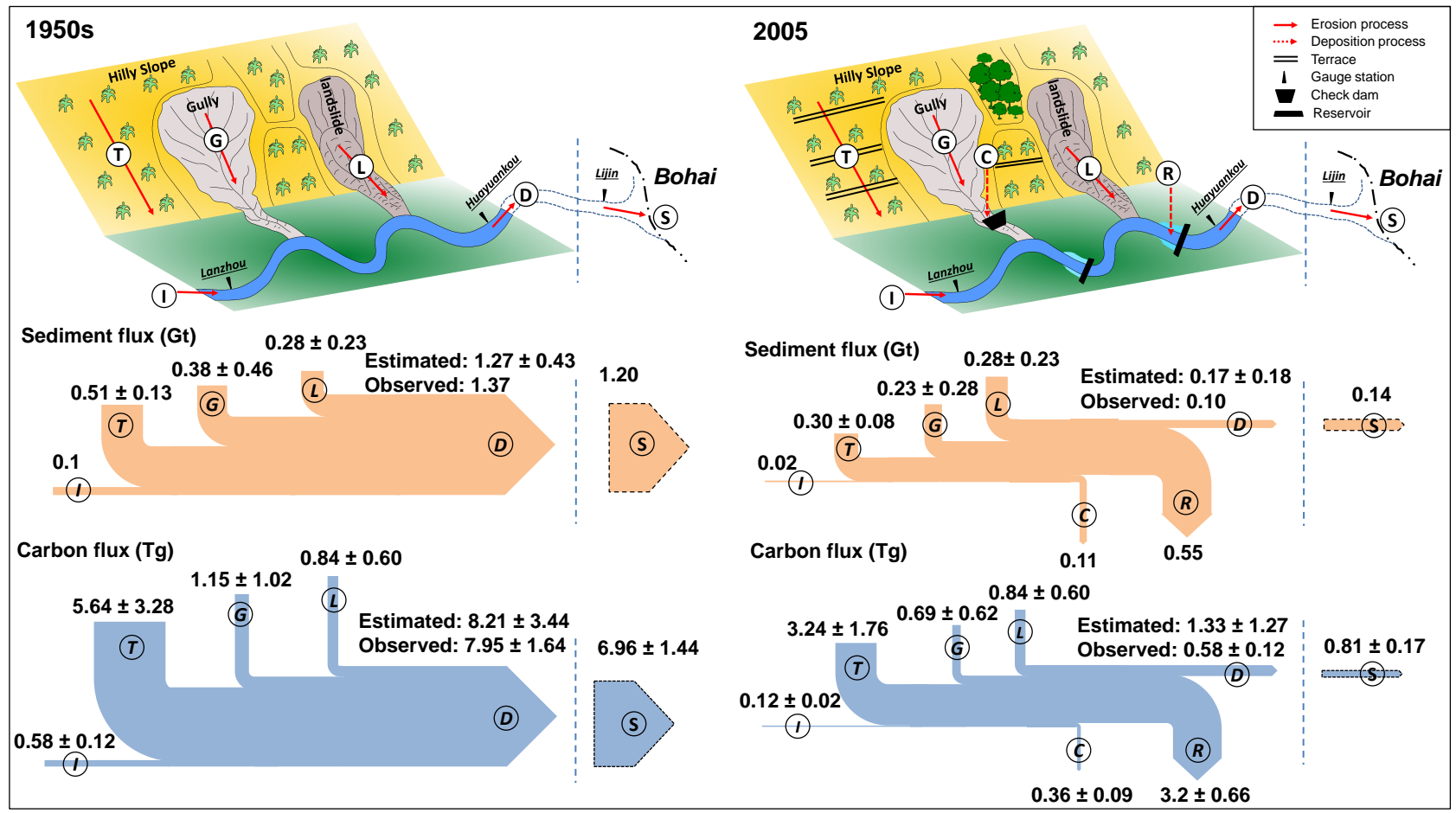

Figure 9. Sediment and carbon budget for the CLP in 1950 and 2005. Sediment input from upstream was the average sediment discharge observed at Lanzhou station (Fig. 1). Sediment export from the CLP was the average sediment discharge observed at Huayuankou. Sediment delivery to the Bohai sea is the averaged sediment discharge observed at Lijin. Characters with a circle represent different erosion and/or deposition processes: I: input from upstream; T: topsoil erosion; G: gully erosion; L: landslides; C: deposition behind check dam; R: deposition in reservoirs; D: sediment/carbon export from CLP; S: delivery to Bohai sea.

firm that this value is realistic, at least for the last centuries, for which an average yield of ca. $1.1 \mathrm{Gt} \mathrm{yr}^{-1}$ was reported (Saito et al., 2001). However, sediment yields have decreased significantly in the last decades and current sediment yield (2000-2010) is, on average $0.10 \mathrm{Gt} \mathrm{yr}^{-1}$ (Ministry of Water Resources of China, 2011). This sharp reduction is not only due to a reduction in sediment mobilization (by ca. $0.36 \mathrm{Gt}$ ) but is also due to a very significant increase in sediment trapping. Recent estimates place the amount of sediment trapped annually in reservoirs on the CLP at $0.55 \mathrm{Gt} \mathrm{yr}^{-1}$, while ca. $0.59 \mathrm{Gt} \mathrm{yr}^{-1}$ is trapped in reservoirs in the whole Yellow River Basin: the annual retention rate strongly increased since 1970 as several major reservoirs on the Yellow River came into operation (Ran et al., 2013a). An additional $0.11 \mathrm{Gt} \mathrm{yr}^{-1}$ is estimated to be retained by smaller conservation structures (check dams) (Jiao et al., 2014; Ran et al., 2004). Overall, increased sediment trapping accounts for ca. $60 \%$ of the total reduction in sediment yield.

Combining all data a sediment budget can be constructed for the CLP under 2005 conditions as well as for the CLP under pre-conservation conditions (1950) (Fig. 9). Comparing the observed average sediment yield with the sediment yield calculated by summing all sediment inputs and sinks shows a very good agreement, both for 1950 and 2005 conditions, confirming that our estimates are indeed of the correct order of magnitude (Fig. 9). Clearly, sediment dynamics on the CLP have dramatically changed since 1950 . Not only have erosion rates been significantly reduced, mainly as a result of terracing and check dam construction, but eroded sediments are now mostly stored within the CLP rather than exported to the Bohai Sea, as was the case under 1950 conditions.

\subsection{The magnitude of the erosion-induced carbon sink}

Combing sediment mobilization by topsoil erosion with the average SOC fraction in the topsoil $(0-20 \mathrm{~cm})$ under different land use (Table 5, Liu et al., 2011), we estimated that under 2005 conditions ca. $3.24 \pm 1.76 \mathrm{Tg} \mathrm{yr}^{-1}$ of SOC was mobilized by topsoil erosion. Sediments from gullied areas contain far less SOC than agricultural topsoil (ca. $3 \pm 0.05 \mathrm{~g} \mathrm{~kg}^{-1}$, Han et al., 2010), resulting in a total SOC mobilization of ca. $0.69 \pm 0.62 \mathrm{Tg} \mathrm{yr}^{-1}$ by gullying. Landslides operate over depth scales similar to those of gullies: assuming that landslide sediments also contain ca. $3 \pm 0.05 \mathrm{~g} \mathrm{~kg}^{-1}$ of SOC, the contribution of landsliding to SOC mobilization may be conservatively estimated at $0.84 \pm 0.60 \mathrm{Tg} \mathrm{yr}^{-1}$. This results in an overall total of ca. $4.77 \pm 1.96 \mathrm{Tg} \mathrm{yr}^{-1}$ of SOC being mobilized under 2005 conditions. As erosion was more intense, 
ca. $7.63 \pm 3.52 \mathrm{Tg} \mathrm{yr}^{-1}$ of SOC was mobilized under 1950 conditions. As is the case for erosion rates, our estimates of SOC mobilization (and hence of the maximum magnitude of the SOC sink) are much lower than other, recently published estimates (e.g. $18 \mathrm{Tg} \mathrm{C} \mathrm{yr}^{-1}$, Ran et al., 2014).

The moderate losses of topsoil constrain the maximum magnitude of the erosion-induced carbon sink, which is at present limited to $4.77 \pm 1.96 \mathrm{Tg} \mathrm{C} \mathrm{yr}^{-1}$. The amount of SOC that was mobilized by erosion, and therefore the potential magnitude of the erosion-induced carbon sink was significantly higher before conservation programs started (7.63 $\pm 3.52 \mathrm{Tg} \mathrm{C} \mathrm{yr}^{-1}$, Fig. 9).

Evidently, the real magnitude of the SOC sink may be significantly different from the total amount of SOC that is being mobilized. The SOC sink magnitude will equal the amount of mobilized SOC (i) if all eroded SOC is dynamically replaced at erosional sites, (ii) net SOC losses during erosion and transport are negligible and (iii) all eroded SOC is permanently buried at depositional sites. In theory, it is even possible for the sink strength to exceed the total amount of SOC mobilized, e.g. when all three conditions above are met and net primary productivity at depositional sites increases significantly due to the deposition of sediment and nutrients (Berhe et al., 2007).

Experimental data suggest that dynamic replacement and carbon export are in near-equilibrium on eroding farmland on the CLP, i.e. all the carbon that is eroded is dynamically replaced by new photosynthesis (Y. Li et al., 2015). Some of the SOC mobilized by gully and landslide erosion will also be replaced by vegetation regrowth on landslide scars and gully beds and sidewalls. It is not clear how important this replacement is but it may be expected to be significant, given the low initial SOC content of these surfaces. A key question remains how much of the eroded carbon is preserved in depositional environments. Nowadays, nearly all sediments and associated SOC mobilized by different erosion processes on the CLP are stored on land (Fig. 9). Studies of colluvial environments on the CLP suggest that a significant amount of the SOC buried by deposition is preserved in such depositional environments (Y. Li et al., 2015). Similarly, reservoirs sediments are known to contain a significant amount of particulate organic carbon, which is likely to be sequestered over timescales up to several centuries (Wang et al., 2015; Zhang et al., 2013). Furthermore, terracing may have temporarily enhanced $\mathrm{C}$ storage as carbon-rich topsoil may be buried and carbon-poor subsoil may be exposed by terrace construction. As most of these depositional environments came only recently into being, their carbon burial efficiency will still be relatively high (Wang et al., 2014b, 2015) and SOC respiration at depositional sites is likely not to exceed $50 \%$ of the total amount of SOC mobilized, placing a lower bound of ca. $2.38 \pm 0.98 \mathrm{Tg} \mathrm{Cyr}^{-1}$ on the magnitude of the erosioninduced carbon sink under 2005 conditions. Clearly this is a rough approximation only: the burial efficiency of SOC does not only depend on SOC burial rates but also on the quality of
Table 3. Comparison of our estimates of the average lateral SOC mobilization rate and net erosion-induced carbon sequestration rate on the CLP with published rates for other regions.

\begin{tabular}{lrr}
\hline Reference & $\begin{array}{r}\text { lateral C mobilization } \\
\left(\mathrm{g} \mathrm{m}^{-2} \mathrm{yr}^{-1}\right)\end{array}$ & $\begin{array}{r}\text { Net erosion-induced } \\
\mathrm{C} \mathrm{sink}\left(\mathrm{g} \mathrm{m}^{-2} \mathrm{yr}^{-1}\right)\end{array}$ \\
\hline Berhe et al. (2007) & 33 & 5 \\
Y. Li et al. (2015) & 42 & 36 \\
Nadeu et al. (2015) & 4.7 & 2.7 \\
Van Oost et al. (2005) & $14.2-17.35$ & $3-10$ \\
Van Oost et al. (2007) & $3.2-21$ & $0.7-5.7$ \\
Harden et al. (1999) & & $10-20$ \\
\hline This study (CLP, 1950) & $12.26 \pm 5.66$ & $6.13 \pm 2.83$ \\
\hline This study (CLP, 2005) & $7.69 \pm 3.15$ & $3.83 \pm 1.58$ \\
\hline
\end{tabular}

soil organic matter (SOM) that is buried (Berhe and Kleber, 2013; Hu et al., 2016) as well as the location in the landscape where burial takes place (Berhe and Kleber, 2013) and the soil type (Hu et al., 2016). A more accurate determination of the lower limit of the erosion-induced $\mathrm{C}$ sink will require a coupling between the key factors controlling $\mathrm{C}$ burial efficiency and geographical data that can be used to map the spatial variation of these controls at the regional scale.

Prior to 1950 the geomorphological cascade was more or less in equilibrium. The amount of sediment mobilized on the CLP approximately equalled the amount of sediment exported to the Bohai Sea (1.1-1.3 $\mathrm{Gt} \mathrm{yr}^{-1}$, Miao et al., 2010, Fig. 9). The lower bound of the erosion induced carbon sink will then be equal to the amount of carbon exported to the Bohai Sea and buried in coastal and distal marine sediments. The OC content of Yellow river sediments is on average ca. $0.58 \pm 0.12 \%$ (Ran et al., 2013b; Wang et al., 2012; Zhang et al., 2013). As the total sediment export by the Yellow River to the Bohai Sea was ca. $1.2 \mathrm{Gt} \mathrm{yr}^{-1}$, ca. $6.96 \pm 1.44 \mathrm{TgC}^{-1}$ was annually exported in particulate form to the Bohai Sea. This amount is very similar to our estimate of the amount of OC mobilized by erosion $\left(7.63 \pm 3.52 \mathrm{Tg} \mathrm{C} \mathrm{yr}^{-1}\right)$ in this period. This suggests that, under 1950 conditions, not only the geomorphological but also the carbon cascade was at near-equilibrium, with the Yellow River exporting an amount of organic carbon similar to the amount delivered to the river systems by hillslope processes. An important consideration is, however, that not all of this carbon will be permanently buried in deltaic and marine sediments: to the best of our knowledge, no data on burial efficiency are available for the Yellow River but a recent review places the carbon burial efficiency of terrestrial OC on continental shelves with high deposition rates $\left(1-10 \mathrm{~g} \mathrm{~cm}^{-2} \mathrm{yr}^{-1}\right)$ between ca. 25 and ca. $80 \%$ (Leithold et al., 2016). Thus, the effective magnitude of the erosion-induced sink under 1950 conditions is likely to be $1.75-5.5 \mathrm{Tg} \mathrm{C} \mathrm{yr}^{-1}$. Clearly, the comparison above only assesses upstream inputs and downstream outputs for the Yellow River. It is well possible that significant exchanges of POC between the river and its flood- 
plain occur between the CLP and the river mouth and that part of the POC exported by the Yellow River results from within-river photosynthesis (Hoffmann et al., 2013; Omengo et al., 2016; Regnier et al., 2013), compensating for the loss of erosion-derived POC by within-river mineralization.

The implementation of soil conservation programs has reduced the maximum strength of the erosion-induced carbon sink on the CLP by $4.58 \pm 1.74 \mathrm{Tg} \mathrm{C} \mathrm{yr}^{-1}$. Although the Grain for Green program still only covers a relatively limited area, its beneficial effects in terms of $\mathrm{C}$ sequestration in biomass and soils are estimated to be ca. $10-12 \mathrm{Tg} \mathrm{C} \mathrm{yr}^{-1}$ : thus, these benefits more than compensate the reduction of the erosion-induced carbon sink that results from afforestation (Feng et al., 2013; Persson et al., 2013).

On a unit area basis, the rate of SOC mobilization by erosion on the CLP is of the same order of magnitude as observed by Berhe et al. (2007) in a small agricultural catchment in Tennessee Valley of California (Table 3). Nadeu et al. (2015) obtained significantly lower mobilization rates for a small agricultural catchment in Belgium, which is due to a combination of moderate erosion rates and the low SOC content of the soil. Van Oost et al. (2007) obtained an average SOC mobilization rates of $15.5 \mathrm{~g} \mathrm{C} \mathrm{m}^{-2} \mathrm{yr}^{-1}$ for 10 hilly catchments in Europe and North America, a value that is also similar to our estimate of SOC mobilization under 1950 conditions. Our estimates of the net $\mathrm{C}$ sink correspond to a sequestration rate of ca. $3.83 \pm 1.58 \mathrm{~g} \mathrm{C} \mathrm{m}^{-2} \mathrm{yr}^{-1}$ under 2005 conditions (assuming a sink strength equal to $50 \%$ of the total $\mathrm{C}$ mobilization) and $6.13 \pm 2.83 \mathrm{~g} \mathrm{C} \mathrm{m}^{-2} \mathrm{yr}^{-1}$ under 1950 conditions for the entire CLP: these numbers are similar to the estimates obtained by Van Oost et al. (2005) for a single field in Belgium (3-10 $\mathrm{g} \mathrm{C} \mathrm{m}^{-2} \mathrm{yr}^{-1}$ ) and Van Oost et al. (2007) for 10 small catchments $\left(0.7-5.7 \mathrm{~g} \mathrm{C} \mathrm{m}^{-2} \mathrm{yr}^{-1}\right)$, while Harden et al. (1999) obtained somewhat higher values (10-20 $\mathrm{g} \mathrm{C} \mathrm{m}^{-2} \mathrm{yr}^{-1}$ ) for small agricultural catchments in Mississippi (Table 3).

\subsection{Nutrient losses and agricultural productivity reduction by soil erosion}

Based on estimates of the $\mathrm{N}$ and $\mathrm{P}$ content of arable topsoil (Table S5, Liu et al., 2013), we estimate that under 1950 conditions annual nitrogen $(\mathrm{N})$ and phosphorous $(\mathrm{P})$ losses amounted to ca. 0.38 and $0.34 \mathrm{Tg}$. Conservation efforts reduced these losses to 0.22 and $0.20 \mathrm{Tg}$ respectively under 2005 conditions (Table 4). These losses incur a very significant cost. In April 2016 the average mineral fertilizer prices in China were ca. $0.47 \mathrm{USD} \mathrm{kg}^{-1} \mathrm{~N}$ and ca. $2.17 \mathrm{USD} \mathrm{kg}^{-1} \mathrm{P}$ (available at: http://www.fert.cn/11003/, 2016). The amount of fertilizers lost by surface erosion is equivalent to a financial loss of ca. 0.10 billion USD for $\mathrm{N}$ and ca. 0.43 billion USD for P. Current N and P losses are less than $20 \%$ of the mineral fertilizer input on the CLP (Table 4). However, this is only because fertilizer inputs have risen dramatically: in 1980 fertilizer inputs were only ca. $25 \%$ of the current
Table 4. Comparison of fertilizer inputs ( $\mathrm{N}$ and $\mathrm{P}$ ) and losses due to topsoil erosion (Tg) on arable land on the CLP in 1980 and 2000. Nutrients inputs were estimated by multiplying fertilizer input per unit area $\left(\mathrm{kg} \mathrm{ha}^{-1}\right)$ (Wang et al., 2014a) with the total cropland area (ha). Nutrient losses due to erosion were estimated by multiplying the amount of sediment mobilized by topsoil erosion and the nutrient content of topsoil under different land uses (Liu et al., 2013).

\begin{tabular}{lcrrr}
\hline Nutrient & Year & $\begin{array}{r}\text { Input } \\
(\mathrm{Tg})\end{array}$ & $\begin{array}{r}\text { Erosion } \\
(\mathrm{Tg})\end{array}$ & loss ratio \\
\hline $\mathrm{N}$ & 1980 & 0.70 & 0.38 & $53.66 \%$ \\
& 2000 & 2.74 & 0.22 & $8.00 \%$ \\
$\mathrm{P}$ & 1980 & 0.39 & 0.34 & $87.64 \%$ \\
& 2000 & 1.28 & 0.20 & $15.37 \%$ \\
\hline
\end{tabular}

(2000) amounts and relative losses of nutrients by erosion exceeded $50 \%$ of the input at that time (Table 4). In 1950, when no mineral fertilizers were used (Zhu and Chen, 2002), nutrient losses by erosion likely exceeded nutrient supply. The reduction of relative nutrient losses is mainly due to the increase of nutrient inputs: the reduction of nutrient losses associated with a reduction of erosion rates is relatively less important (Wang et al., 2014a).

The average TER on arable land is now close to what was long considered to be an acceptable soil loss tolerance level (Jiao, 2014; Renard et al., 1997). While topsoil erosion at this rate may still threaten agricultural productivity, this threat would only materialize over long time spans (Bakker et al., 2004; den Biggelaar et al., 2003; Lal, 2003). In high-input agricultural systems such as the CLP, a loss of $0.1 \mathrm{~m}$ of soil induces, on average, an inherent productivity loss of ca. $4 \%$ on soils with a limited water holding capacity (Bakker et al., 2004). At current erosion rates, such a loss would take, on average, ca. 100-130 years on the arable land of the CLP. Productivity losses on deep soils are lower, which explains why very significant gains in productivity could be realized on the CLP over the last 50 years, despite the heavily degraded status of some of the soils (Bakker et al., 2004). Average numbers hide a large variability: even under current conditions, topsoil erosion rates exceed $10 \mathrm{tha}^{-1} \mathrm{yr}^{-1}$ on $40 \%$ of the arable land calling for targeted conservation efforts to reduce local TER even further.

\section{Conclusions}

The mechanisms of the erosion processes modifying the Earth's surface are nowadays well understood. However, assessing their impact at the regional or global scale does not only depend on our level of process understanding but also on the correct extrapolation of the data we collect, often over relatively small areas. By doing so for the CLP we have shown that current perceptions regarding the intensity of soil ero- 
sion and its effects (both negative and positive) need to be revised.

In this study we developed and applied an empirical procedure to estimate topsoil erosion rates on the CLP. We showed that, under 2005 conditions, topsoil erosion rates on the CLP were 3 to 9 times lower than previously assumed. Earlier studies led to strong overestimations largely because erosion models were applied over large areas with inappropriate parameter values and/or using inadequate input data. Also, gully erosion and landslides combined mobilize more sediment than topsoil erosion. Our revision also limits the magnitude of the erosion-induced carbon sink to maximum ca. $4.77 \pm 1.96 \mathrm{Tg} \mathrm{yr}^{-1}$, with a most likely value of ca. $2-$ $3 \mathrm{Tg} \mathrm{yr}^{-1}$, which is, again, much lower than earlier estimates. Further constraining the uncertainty on the magnitude of the erosion-induced carbon sink under current conditions more accurately will require, in the first place, a better understanding of the controls on carbon burial efficiency on land, where most of the carbon burial is now taking place.

Prior to the implementation of conservation programs, erosion and hence OC mobilization rates on the CLP were significantly higher, with the system being in near equilibrium (i.e. sediment and carbon mobilization were approximately equal to sediment and carbon export to the sea). As significantly more carbon was mobilized by erosion (ca. $7.63 \pm 3.52 \mathrm{Tg} \mathrm{C} \mathrm{yr}^{-1}$ ) the magnitude of the erosioninduced carbon sink was probably also higher, with its magnitude mainly determined by the carbon burial efficiency at sea which is currently also poorly constrained (25-80\%). The fact that conservation programs reduce the magnitude of the erosion-induced carbon sink does not imply that soil conservation would lead to an increased emission of soil organic carbon to the atmosphere. Modern conservation programs heavily rely on the use of permanent vegetation: the amount of carbon stored in this vegetation may offset or even surpass the reduction of the erosion-induced carbon sink, thereby increasing terrestrial carbon storage.

Under current conditions, nutrient losses due to erosion are no direct threat to agricultural productivity. This is in the first place due to the increase of mineral fertilizer inputs since the 1980s. Although soil conservation measures have significantly reduced soil erosion and hence nutrient losses, their relative impact on the nutrient balance is less important. It should be kept in mind though that, on the long term, productivity losses may still occur as soil erosion not only affects the nutrient status, but also physical soil properties such as the soil's water holding capacity.

\section{Data availability}

Land use dataset of China (1980s and 2005) can be applied from the Resources and Environmental Centre of the Institute of Geographical Sciences and Natural Resources Research, Chinese Academic of Sciences (http://www.geodata. $\mathrm{cn} /$ ). SRTM dataset ( $90 \mathrm{~m}$ resolution) of China can be obtained from the Environmental and Ecological Science Data Centre for West China, National Science Foundation of China (http://westdc.westgis.ac.cn/).

\section{The Supplement related to this article is available online at doi:10.5194/bg-13-4735-2016-supplement.}

Author contributions. Gerard Govers conceived and directed the project. Jianlin Zhao collected the data and conducted the calculation and analysis. All authors contributed to interpretation and writing.

Acknowledgements. We acknowledge the China Scholarship Council (CSC) for supporting J. Zhao's research at KU Leuven. We thank Prof. Jiyuan Liu at the Institute of Geographical Sciences and Natural Resources Research, Chinese Academic of Sciences for his help to obtain land use data set.

Edited by: M. Bahn

Reviewed by: two anonymous referees

\section{References}

Bakker, M. M., Govers, G., and Rounsevell, M. D.: The crop productivity-erosion relationship: an analysis based on experimental work, Catena, 57, 55-76, 2004.

Berhe, A. A. and Kleber, M.: Erosion, deposition, and the persistence of soil organic matter: Mechanistic considerations and problems with terminology, Earth Surf. Proc. Land., 38, 908912, 2013.

Berhe, A. A., Harte, J., Harden, J. W., and Torn, M. S.: The Significance of the Erosion-induced Terrestrial Carbon Sink, Bioscience, 57, 337-346, 2007.

Blanco-Canqui, H. and Lal, R.: Soil and Water Conservation, in Principles of Soil Conservation and Management SE - 1, Springer Netherlands, Dordrecht, 1-19, 2008.

Cai, Q.: Soil erosion and management on the Loess Plateau, J. Geogr. Sci., 11, 53-70, 2001.

Cammeraat, L. H.: A review of two strongly contrasting geomorphological systems within the context of scale, Earth Surf. Proc. Land., 27, 1201-1222, 2002.

Cerdan, O., Le Bissonnais, Y., Govers, G., Lecomte, V., van Oost, K., Couturier, A., King, C., and Dubreuil, N.: Scale effect on runoff from experimental plots to catchments in agricultural areas in Normandy, J. Hydrol., 299, 4-14, 2004.

Cerdan, O., Govers, G., Le Bissonnais, Y., Van Oost, K., Poesen, J., Saby, N., Gobin, A., Vacca, A., Quinton, J., Auerswald, K., Klik, A., Kwaad, F. J. P. M., Raclot, D., Ionita, I., Rejman, J., Rousseva, S., Muxart, T., Roxo, M. J., and Dostal, T.: Rates and spatial variations of soil erosion in Europe: A study based on erosion plot data, Geomorphology, 122, 167-177, 2010. 
Chang, R., Fu, B., Liu, G., and Liu, S.: Soil carbon sequestration potential for "grain for green" project in Loess Plateau, China, Environ. Manage., 48, 1158-1172, 2011.

Chen, L., Wei, W., Fu, B. and Lu, Y.: Soil and water conservation on the Loess Plateau in China: review and perspective, Prog. Phys. Geogr., 31, 389-403, 2007.

den Biggelaar, C., Lal, R., Wiebe, K., Eswaran, H., Breneman, V., and Reich, P.: The Global Impact Of Soil Erosion On Productivity: II: Effects On Crop Yields And Production Over Time, Adv. Agron., 81, 49-95, 2003.

Deng, L., Shangguan, Z., and Li, R.: Effects of the grain-for-green program on soil erosion in China, Int. J. SEDIMENT Res., 27, 120-127, 2013.

Derbyshire, E., Meng, X., and Dijkstra, T. A.: Landslides in the thick loess terrain of north-west China, John Wiley \& Sons Incorporated, Chichesher, 2000.

Feng, X., Fu, B., Lu, N., Zeng, Y., and Wu, B.: How ecological restoration alters ecosystem services: an analysis of carbon sequestration in China's Loess Plateau, Sci. Rep., 3, 2846, doi:10.1038/srep02846, 2013.

Fu, B., Liu, Y., Lü, Y., He, C., Zeng, Y., and Wu, B.: Assessing the soil erosion control service of ecosystems change in the Loess Plateau of China, Ecol. Complex., 8, 284-293, 2011.

Fu, B.-J., Zhang, Q.-J., Chen, L.-D., Zhao, W.-W., Gulinck, H., Liu, G.-B., Yang, Q.-K., and Zhu, Y.-G.: Temporal change in land use and its relationship to slope degree and soil type in a small catchment on the Loess Plateau of China, Catena, 65, 41-48, 2006.

Govers, G., Quine, T. A., Desmet, P. J. J., and Walling, D. E.: The relative contribution of soil tillage and overland flow erosion to soil redistribution on agricultural land, Earth Surf. Proc. Land., 21, 929-946, 1996.

Han, F., Hu, W., Zheng, J., Du, F., and Zhang, X.: Estimating soil organic carbon storage and distribution in a catchment of Loess Plateau, China, Geoderma, 154, 261-266, 2010.

Harden, J. W., Sharpe, J. M., Parton, W. J., Ojima, D. S., Fries, T. L., Huntington, T. G., and Dabney, S. M.: Dynamic replacement and loss of soil carbon on eroding cropland, Global Biogeochem. Cy., 13, 885-901, 1999.

Ho, P.-T.: The loess and the origin of Chinese agriculture, Am. Hist. Rev., 75, 1-36, 1969.

Hoffmann, T., Schlummer, M., Notebaert, B., Verstraeten, G., and Korup, O.: Carbon burial in soil sediments from Holocene agricultural erosion, Central Europe, Global Biogeochem. Cy., 27, 828-835, 2013.

Hu, Y., Berhe, A. A., Fogel, M. L., Heckrath, G. J., and Kuhn, N. J.: Transport-distance specific SOC distribution: Does it skew erosion induced C fluxes?, Biogeochemistry, 128, 339-351, doi:10.1007/s10533-016-0211-y, 2016.

Jiao, J.: Countermeasures to Prevent Water Erosion in the Loess Plateau of China, in: Restoration and Development of the Degraded Loess Plateau, China SE - 14, edited by: Tsunekawa, A., Liu, G., Yamanaka, N., and Du, S., Springer Japan, Tokyo, 183198, 2014

Jiao, J., Wang, Z., Zhao, G., Wang, W., and Mu, X.: Changes in sediment discharge in a sediment-rich region of the Yellow River from 1955 to 2010: implications for further soil erosion control, J. Arid Land, 6, 540-549, 2014.
Jobbágy, E. G. and Jackson, R. B.: The vertical distribution of soil organic carbon and its relation to climate and vegetation, Ecol. Appl., 10, 423-436, 2000.

Jobbágy, E. G. and Jackson, R. B.: The distribution of soil nutrients with depth: global patterns and the imprint of plants, Biogeochemistry, 53, 51-77, 2001.

Lal, R.: Soil erosion and the global carbon budget, Environ. Int., 29, 437-50, 2003.

Leithold, E. L., Blair, N. E., and Wegmann, K. W.: Source to sink sedimentary systems and the global C-cycle: A river runs through it, Earth-Science Rev., 153, 30-42, 2016.

Li, W., Huang, R., Pei, X., and Zhang, X.: Historical Co-seismic Landslides Inventory and Analysis Using Google Earth: A Case Study of 1920 M8.5 Haiyuan Earthquake, China, in: Engineering Geology for Society and Territory - Volume 2 SE - 118, edited by: Lollino, G., Giordan, D., Crosta, G. B., Corominas, J., Azzam, R., Wasowski, J., and Sciarra, N., Springer International Publishing, Cham, 709-712, 2015.

Li, X., Dodson, J., Zhou, X., Zhang, H., and Masutomoto, R.: Early cultivated wheat and broadening of agriculture in Neolithic China, The Holocene, 5, 555-560, 2007.

Li, Y., Quine, T. A., Yu, H. Q., Govers, G., Six, J., Gong, D. Z., Wang, Z., Zhang, Y. Z., and Van Oost, K.: Sustained high magnitude erosional forcing generates an organic carbon sink: Test and implications in the Loess Plateau, China, Earth Planet. Sci. Lett., 411, 281-289, 2015.

Liu, B. Y., Nearing, M. A., Shi, P. J., and Jia, Z. W.: Slope Length Effects on Soil Loss for Steep Slopes Slope, Soil Sci. Soc. Am. J., 64, 1759-1763, 2000.

Liu, G.: Soil conservation and sustainable agriculture on the Loess Plateau: challenges and prospects, Ambio, 28, 663-668, 1999.

Liu, Z., Shao, M., and Wang, Y.: Effect of environmental factors on regional soil organic carbon stocks across the Loess Plateau region, China, Agric. Ecosyst. Environ., 142, 184-194, 2011.

Liu, Z.-P., Shao, M.-A., and Wang, Y.-Q.: Spatial patterns of soil total nitrogen and soil total phosphorus across the entire Loess Plateau region of China, Geoderma, 197, 67-78, 2013.

Lowdermilk, W. C.: Conquest of the land through 7,000 years, US Department of Agriculture, Natural Resources Conservation Service, Washington, 1953.

Meng, X. and Derbyshire, E.: Landslides and their control in the Chinese Loess Plateau: models and case studies from Gansu Province, China, Geol. Soc. London, Eng. Geol. Spec. Publ., 15, 141-153, 1998.

Miao, C., Ni, J., and Borthwick, A. G. L.: Recent changes of water discharge and sediment load in the Yellow River basin, China, Prog. Phys. Geogr., 34, 541-561, 2010.

Ministry of Water Resources of China: China River Sediment Bulletin, China Waterpower Press, Beijing, China, 2011.

Montgomery, D. R.: Soil erosion and agricultural sustainability, P. Natl. Acad. Sci. USA, 104, 13268-72, 2007.

Nadeu, E., Gobin, A., Fiener, P., van Wesemael, B., and van Oost, K.: Modelling the impact of agricultural management on soil carbon stocks at the regional scale: The role of lateral fluxes, Glob. Change Biol., 21, 3181-3192, 2015.

Nearing, M. A.: A single, continuous function for slope steepness influence on soil loss, Soil Sci. Soc. Am. J., 61, 917-919, 1997. 
Nearing, M. A., Govers, G., and Norton, L. D.: Variability in Soil Erosion Data from Replicated Plots, Soil Sci. Soc. Am. J., 63, 1829, 1999.

Omengo, F. O., Geeraert, N., Bouillon, S., and Govers, G.: Deposition and fate of organic carbon in floodplains along a tropical semi-arid lowland river (Tana River, Kenya), J. Geophys. Res.Biogeosci., 121, 1131-1143, doi:10.1002/2015JG003288, 2016.

Van Oost, K., Govers, G., and Desmet, P.: Evaluating the effects of changes in landscape structure on soil erosion by water and tillage, Ecology, 15, 577-589, 2000.

Van Oost, K., Govers, G., Quine, T. A., Heckrath, G., Olesen, J. E., De Gryze, S., and Merckx, R.: Landscape-scale modeling of carbon cycling under the impact of soil redistribution: The role of tillage erosion, Global Biogeochem. Cy., 19, GB4014, doi:10.1029/2005GB002471, 2005.

Van Oost, K., Quine, T. A. A., Govers, G., De Gryze, S., Six, J., Harden, J. W., Ritchie, J. C., McCarty, G. W., Heckrath, G., Kosmas, C., Giraldez, J. V, da Silva, J. R. M., and Merckx, R.: The impact of agricultural soil erosion on the global carbon cycle, Science, 318, 626-629, 2007.

Parsons, A. J. and Foster, I. D. L.: What can we learn about soil erosion from the use of ${ }^{137} \mathrm{Cs}$ ?, Earth-Sci. Rev., 108, 101-113, 2011.

Persson, M., Moberg, J., Ostwald, M., and Xu, J.: The Chinese Grain for Green Programme: assessing the carbon sequestered via land reform, J. Environ. Manage., 126, 142-6, 2013.

Pimentel, D., Harvey, C., Resosudarmo, P., Sinclair, K., Kurz, D., McNair, M., Crist, S., Shpritz, L., Fitton, L., Saffouri, R., and Blair, R.: Environmental and economic costs of soil erosion and conservation benefits, Science, 267, 1117-1123, 1995.

Quinton, J. N., Govers, G., Van Oost, K., and Bardgett, R. D.: The impact of agricultural soil erosion on biogeochemical cycling, Nat. Geosci., 3, 311-314, 2010.

Ran, D., Luo, Q., and Wang, H.: Effect of soil-retaining dams on flood and sediment reduction in middle reaches of yellow river, J. Hydraul. Eng., 35, 7-13, 2004.

Ran, L., Lu, X. X., Xin, Z., and Yang, X.: Cumulative sediment trapping by reservoirs in large river basins: A case study of the Yellow River basin, Global Planet. Change, 100, 308-319, 2013a.

Ran, L., Lu, X. X., Sun, H., Han, J., Li, R., and Zhang, J.: Spatial and seasonal variability of organic carbon transport in the Yellow River, China, J. Hydrol., 498, 76-88, 2013 b.

Ran, L., Lu, X. X., and Xin, Z.: Erosion-induced massive organic carbon burial and carbon emission in the Yellow River basin, China, Biogeosciences, 11, 945-959, doi:10.5194/bg-11945-2014, 2014.

Regnier, P., Friedlingstein, P., Ciais, P., Mackenzie, F. T., Gruber, N., Janssens, I. A., Laruelle, G. G., Lauerwald, R., Luyssaert, S., Andersson, A. J., Arndt, S., Arnosti, C., Borges, A. V., Dale, A. W., Gallego-Sala, A., Goddéris, Y., Goossens, N., Hartmann, J., Heinze, C., Ilyina, T., Joos, F., LaRowe, D. E., Leifeld, J., Meysman, F. J. R., Munhoven, G., Raymond, P. A., Spahni, R., Suntharalingam, P., and Thullner, M.: Anthropogenic perturbation of the carbon fluxes from land to ocean, Nat. Geosci., 6, 597-607, 2013.

Renard, K. G., Foster, G. R., Weesies, G. A., McCool, D. K., and Yoder, D. C.: Predicting soil erosion by water: a guide to conservation planning with the revised universal soil loss equation
(RUSLE), in Agriculture Handbook (Washington), US Government Printing Office, 1997.

Saito, Y., Yang, Z., and Hori, K.: The Huanghe (Yellow River) and Changjiang (Yangtze River) deltas: a review on their characteristics, evolution and sediment discharge during the Holocene, Geomorphology, 41, 219-231, 2001.

Schnitzer, S., Seitz, F., Eicker, A., Guntner, A., Wattenbach, M., and Menzel, A.: Estimation of soil loss by water erosion in the Chinese Loess Plateau using Universal Soil Loss Equation and GRACE, Geophys. J. Int., 193, 1283-1290, 2013.

Shi, H. and Shao, M.: Soil and water loss from the Loess Plateau in China, J. Arid Environ., 45, 9-20, 2000.

Shi, S. and Han, P.: Estimating the soil carbon sequestration potential of China's Grain for Green Project, Global Biogeochem. Cy., 28, 1279-1294, 2014.

Sun, W., Shao, Q., and Liu, J.: Soil erosion and its response to the changes of precipitation and vegetation cover on the Loess Plateau, J. Geogr. Sci., 23, 1091-1106, 2013.

Sun, W., Shao, Q., Liu, J., and Zhai, J.: Assessing the effects of land use and topography on soil erosion on the Loess Plateau in China, Catena, 121, 151-163, 2014.

Tang, K., Xiong, G., Liang, J., Jing, K., Zhang, S., Chen, Y., and $\mathrm{Li}, \mathrm{S}$. : Varieties of erosion and runoff sediment in Yellow River Basin, Chinese Sciences and Technique Press, Beijing, 1993.

Torri, D. and Poesen, J.: The effect of soil surface slope on raindrop detachment, Catena, 19, 561-578, 1992.

Trimble, S. W. and Crosson, P.: US Soil Erosion Rates: Myth and Reality, Science, 289, 248-250, 2000.

Tsunekawa, A., Liu, G., Yamanaka, N., and Du, S.: Restoration and Development of the Degraded Loess Plateau, China, edited by: Tsunekawa, A., Liu, G., Yamanaka, N., and Du, S., Springer Japan, Tokyo, 2014.

Van Rompaey, A. J. J., Verstraeten, G., Van Oost, K., Govers, G., and Poesen, J.: Modelling mean annual sediment yield using a distributed approach, Earth Surf. Proc. Land., 26, 1221-1236, 2001.

Walling, D. E. and Quine, T. A.: The use of caesium-137 measurements in soil erosion surveys, in Erosion and sediment transport monitoring programmes in river basins, IAHS publication, 210, 143-152, 1992.

Wang, X., Ma, H., Li, R., Song, Z., and Wu, J.: Seasonal fluxes and source variation of organic carbon transported by two major Chinese Rivers?: The Yellow River and Changjiang (Yangtze) River, Global Biogeochem. Cy., 26, 1-10, 2012.

Wang, X., Tong, Y., Gao, Y., Gao, P., Liu, F., Zhao, Z., and Pang, Y.: Spatial and temporal variations of crop fertilization and soil fertility in the loess plateau in china from the 1970s to the 2000s, PLoS One, 9, e0112273, doi:10.1371/journal.pone.0112273, 2014a.

Wang, Z., Van Oost, K., Lang, A., Quine, T., Clymans, W., Merckx, R., Notebaert, B., and Govers, G.: The fate of buried organic carbon in colluvial soils: a long-term perspective, Biogeosciences, 11, 873-883, doi:10.5194/bg-11-873-2014, 2014 b.

Wang, Z., Van Oost, K., and Govers, G.: Predicting the long-term fate of buried organic carbon in colluvial soils, Global Biogeochem. Cy., 29, 65-79, 2015.

Wischmeier, W. H. and Smith, D. D.: Predicting rainfall erosion losses-A guide to conservation planning, DC: United States Department of Agriculture, Washington, 1978. 
Xu, X., Zhang, H., and Zhang, O.: Development of check-dam systems in gullies on the Loess Plateau, China, Environ. Sci. Pol., 7, 79-86, 2004.

Yue, Y., Ni, J., Ciais, P., Piao, S., Wang, T., Huang, M., and Borthwick, A. G. L.: Lateral transport of soil carbon and land - atmosphere $\mathrm{CO}_{2}$ flux induced by water erosion in China, P. Natl. Acad. Sci. USA, 113, 6617-6622, 2016.

Zhang, D. and Wang, G.: Study of the 1920 Haiyuan earthquakeinduced landslides in loess (China), Eng. Geol., 94, 76-88, 2007.

Zhang, K., Li, S., Peng, W., and Yu, B.: Erodibility of agricultural soils on the Loess Plateau of China, Soil Tillage Res., 76, 157165, 2004.

Zhang, K., Dang, H., Tan, S., Cheng, X., and Zhang, Q.: Change in soil organic carbon following the "grain-for-green" programme in China, L. Degrad. Dev., 21, 13-23, 2010.
Zhang, L. J., Wang, L., Cai, W.-J., Liu, D. M., and Yu, Z. G.: Impact of human activities on organic carbon transport in the Yellow River, Biogeosciences, 10, 2513-2524, doi:10.5194/bg-10-25132013, 2013.

Zhang, X., Long, Y., He, X., Fu, J., and Zhang, Y.: A simplified $137 \mathrm{Cs}$ transport model for estimating erosion rates in undisturbed soil, J. Environ. Radioact., 99, 1242-6, 2008a.

Zhang, X., Zhang, L., Zhao, J., Rustomji, P., and Hairsine, P.: Responses of streamflow to changes in climate and land use/cover in the Loess Plateau, China, Water Resour. Res., 44, 1-12, 2008b.

Zhao, G., Mu, X., Wen, Z., Wang, F., and Gao, P.: Soil erosion, conservation, and eco-environment changes in the loess plateau of china, Land. Degrad. Dev., 24, 499-510, 2013.

Zhu, Z. L. and Chen, D. L.: Nitrogen fertilizer use in China - Contributions to food production, impacts on the environment and best management strategies, Nutr. Cycl. Agroecosys., 63, 117127, 2002. 